\title{
Od Ongulumbashe do Cassingi - obozy wojskowe i cywilne Ludowej Wyzwoleńczej Armii Namibii
}

Streszczenie. Republika Namibii ogłosiła niepodległość w 1990 r., po ponad 25 latach wojny o wyzwolenie spod południowoafrykańskiej dominacji. Tożsamość młodego narodu wykuwała się jednak znacznie wcześniej, a jeden z najważniejszych elementów budowania wspólnoty, która zawierała się w haśle SWAPO ,jedna Namibia, jeden człowiek, jeden naród”, stanowiły obozy dla cywilnych uchodźców i oddziałów partyzanckich Ludowej Wyzwoleńczej Armii Namibii (PLAN), znajdujące się w Angoli, Zambii i Tanzanii. Celem niniejszego artykułu jest wskazanie kluczowych momentów w historii namibijskich obozów w Angoli, wybranych elementów ich funkcjonowania oraz roli, jaką odegrały w dziejach młodego państwa i jego mieszkańców.

Słowa kluczowe: Namibia, obozy, SWAPO, PLAN, niepodległość.

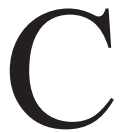

hoć sam fakt istnienia obozów namibijskiej partyzantki na terytorium Angoli pojawia się w literaturze wielokrotnie, rzadko towarzyszy mu refleksja nad sposobem ich funkcjonowania oraz nad tym - co ma szczególne znaczenie - jaką rolę spełniały ówcześnie i jakie znaczenie mają obecnie dla budowy narracji o wspólnocie narodowej Namibijczyków. Spośród historyków dotykających problemów niepodległości Namibii, jedyną osobą trwale zajmującą się tematyką obozów jest Christian A. Williams, który poświęcił im swoją pracę doktorską i zaangażował się w duży projekt, którego celem było spopularyzowanie, unaocznienie znaczenia istnienia obozów wśród samych Namibijczyków.

Tematem niniejszej pracy są wybrane obozy wojskowe i cywilne zakładane przez Ludową Wyzwoleńczą Armię Namibii (PLAN ${ }^{1}$ ), wykonawcy polityki Organizacji Ludu Afryki Południowo-Zachodniej (SWAPO²). Ze względu na

* Wydział Filozoficzno-Historyczny, Studium Doktoranckie Nauk Humanistycznych, e-mail: anna.karolina.szczepanska@gmail.com.

1 Ang. People's Liberation Army of Namibia.

2 Ang. South West Africa People's Organisation. 
rozległość tematu, w swoim artykule skupiam uwagę głównie na obozach znajdujących się na terytorium Angoli, gdyż odegrały one decydującą rolę w dziejach wojny o wyzwolenie spod południowoafrykańskiej dominacji, a wiele wydarzeń, które miały wówczas miejsce, rzutuje również na współczesną Namibię. Celem artykułu jest prezentacja wybranych aspektów funkcjonowania obozów oraz ich znaczenia dla konsolidacji mieszkańców Namibii, dążących do posiadania niepodległego państwa.

\section{Geneza tworzenia obozów}

Afryka Południowo-Zachodnia ${ }^{3}$, po niemal trzydziestoletniej dominacji Niemców na swoim obszarze, w roku 1919 - na mocy traktatu wersalskiego - otrzymała status terytorium powierniczego i znalazła się pod władzą Związku Południowej Afryki ${ }^{4}$. Polityka niemieckich władz kolonialnych oparta na segregacji rasowej, u progu lat dwudziestych XX w. została przejęta przez nową administrację urzędującą w Pretorii. W 1948 r., kiedy wybory parlamentarne w ZPA wygrała Partia Nacjonalistyczna pod przywództwem Daniela F. Malana, stosunek rządu, zarówno do czarnoskórych mieszkańców ZPA, jak i Namibii, uległ znacznemu zaostrzeniu, czego wyrazem było ustanowienie doktryny apartheidu, stanowiącej obowiązujące prawo.

Pomimo znacznych nacisków ze strony społeczności międzynarodowej, władze południowoafrykańskie nie ustępowały ze swojego stanowiska i nie łagodziły prowadzonej polityki. Dodatkowo, od 1949 r. uznawały Namibię za integralną część własnego państwa, nie przyjmując, że stanowisko to stoi w sprzeczności z postanowieniami ONZ, które określały Afrykę Południowo-Zachodnią jako terytorium mandatowe, znajdujące się pod czasową administracją ZPA, mającego obowiązek przygotowywać je do przyszłej samodzielności, a ostatecznie niepodległości ${ }^{5}$.

Ludność Afryki Południowo-Zachodniej, poddana prawom opartym na doktrynie apartheidu, nie widząc nadziei na poprawę swojej sytuacji w najbliższej przyszłości, wzorem innych społeczności w całej Afryce, rozpoczęła tworzenie organizacji, które występowałyby w imieniu wszystkich mieszkańców Namibii. Pierwszą z nich był Kongres Ludu Owambo ${ }^{6}$, powołany do życia w 1958 r.,

${ }^{3}$ Nazwa Namibia oficjalnie zaczęła funkcjonować w 1968 r., decyzją ONZ. Na potrzeby pracy obydwie nazwy tego obszaru będą stosowe naprzemiennie, aby uniknąć powtórzeń.

${ }^{4}$ Nazwa Związek Południowej Afryki funkcjonowała do 1961 r., kiedy kraj ten odrzucił ostatnie zależności od Wielkiej Brytanii i przyjął nazwę Republiki Południowej Afryki. Nazwa ZPA funkcjonowała w latach 1910-1961.

${ }^{5}$ Szeroko o problemie Namibii w ONZ m.in.: C.J. Ts ok od a y i, Namibia's Independence Struggle. The Role of United Nations, Bloomington 2011; R. D a le, The Namibian War of Independence 1966-1989. Diplomatic, Economic and Military Campaigns, Jefferson 2014.

${ }^{6}$ Ang. Ovamboland People's Congress. 
przemianowany rok później na Organizację Ludu Owambo ${ }^{7}$. Przez krótki czas prężnie funkcjonowała również partia SWANU ${ }^{8}$ (Narodowa Unia Afryki Południowo-Zachodniej), w której dominowała grupa etniczna Hererów. Partia ta powstała w 1959 r., lecz dość szybko utraciła zagraniczne poparcie, choć na politycznej scenie Namibii funkcjonuje do tej pory ${ }^{9}$. Strukturą, która odegrała decydującą rolę w walce o niepodległość była SWAPO ${ }^{10}$, utworzona w 1960 r. ${ }^{11}$, skupiająca przede wszystkim ludność Owambo. Na jej czele stanął Sam Nujoma, przyszły prezydent niepodległego państwa.

Do połowy lat sześćdziesiątych naczelnym zadaniem, jakie postawiły przed sobą władze SWAPO, było zainteresowanie kwestią Namibii społeczności międzynarodowej poprzez uczestnictwo w obradach Zgromadzenia Ogólnego ONZ. Obecność wśród światowych przywódców, polityków i dziennikarzy z całego świata wspomagała poszukiwania sprzymierzeńców z różnych części globu. Działania na polu dyplomatycznym okazały się jednak niewystarczające. Uświadomiono sobie ten fakt już na początku lat sześćdziesiątych, co spowodowało wysłanie pierwszych rekrutów na szkolenia wojskowe do Algierii, a niedługo później do Egiptu, Ghany, Chin, Korei Północnej, ZSRS i utworzenie obozu (początkowo tylko wojskowego, następnie miał on również charakter cywilny) Kongwa, w Tanzanii ${ }^{12}$. W 1966 r., po wieloletnich bataliach na linii ONZ-RPA, Międzynarodowy trybunał w Hadze uznał, że okupacji Namibii przez RPA nie można uznać za nielegalną. Dla działaczy SWAPO, przebywających poza granicami kraju i pozostających w ukryciu na terytorium Namibii, był to duży cios. Uznano, że droga do wyzwolenia spod władzy RPA prowadzi przez walkę z bronią w ręku. Wkrótce wydano decyzję o rozpoczęciu wojny przeciwko południowoafrykańskiej dominacji ${ }^{13}$. Pierwsze, nietrwałe obozy tworzone przez oddziały partyzanckie zaczęły powstawać w Zambii ${ }^{14}$. Sygnał do rozpoczęcia działań przeciwko siłom południowoafrykańskim wydano w sierpniu 1966 r. Do pierwszego starcia doszło 26 sierpnia na terenie obozu Ongulumbashe, ulokowanego po namibijskiej stronie granicy w Owambolandzie.

${ }^{7}$ Ang. Ovamboland People's Organisation. R. Da le, op. cit., s. 69.

${ }^{8}$ Ang. South West African National Union.

9 R. Dale, op. cit., s. 75.

${ }^{10}$ Ang. South West African People's Organisation.

${ }^{11}$ SWAPO miało być w zamyśle organizacją ponadplemienną, jednoczącą wszystkich mieszkańców kraju. Ostatecznie najwięcej członków partii było Ovambo, najliczniejszej grupy etnicznej w Namibii. Przywódcy ludności Herero (drugiej pod względem wielkości) odmówili zasiadania w strukturach SWAPO, zakładając własne ugrupowanie, SWANU. Vide: M. Walla ce, A History of Namibia, London 2011, s. 249.

${ }^{12}$ S. N u j o m a, Where Other Waverd. The Autobiography of Sam Nujoma, London 2001, s. 159.

${ }_{13}$ P.H. Katj a vi vi, A History of Resistance in Namibia, New York 1990, s. 59.

${ }^{14}$ Modern African Wars, Sout West Africa, http://kohlibri.e-bookshelf.de/products/readingepub/page/13/product-id/707743/title/Modern\%2BAfrican\%2BWars\%2B\%25283\%2529.html?firm= \%22OSPREY\%22 (dostęp: 16 XI 2017). 


\section{Obozy - znaczenie i funkcjonowanie}

Obozy wojskowe i cywilne SWAPO stanowią jeden z najważniejszych elementów budowania narracji historycznej we współczesnej Namibii. Jednocześnie przynależą one do szerszego kontekstu, jakim było życie na wygnaniu. Ucieczka z kraju dla wielu osób była jedyną szansą, aby nie trafić do południowoafrykańskiego więzienia. To na obczyźnie Namibijczycy, początkowo ci skupieni wokół partii SWAPO, a z czasem wszyscy, bez względu na sympatie polityczne, zbudowali podwaliny przyszłego niepodległego państwa. $Z$ tego powodu odwołania do tradycji wygnańczej mają obecnie tak duże znaczenie i stanowią klucz do zrozumienia współczesnej Namibii.

W historiografii namibijskiej w odniesieniu do mieszkańców obozów rzadko używa się określenia uchodźcy. Są to raczej freedom fighters - bojownicy o wolność ${ }^{15}$. To właśnie w obozach rozsianych wzdłuż granicy z Afryką Południowo-Zachodnią, na terenie Zambii, a później Angoli skupiła się znacząca siła (nie tylko w sensie ilościowym, ale również ,jakościowym”) mieszkańców okupowanego kraju. Potwierdzeniem znaczenia tego elementu dla dziejów współczesnej Namibii jest jedno z najważniejszych świąt państwowych - Dzień Bohaterów, obchodzone 26 sierpnia, upamiętniające początek wojny o niepodległość Namibii (26 sierpnia 1966 r.), która rozpoczęła się w Ongulumbashe, jedynym obozie PLAN założonym na terytorium Afryki Południowo-Zachodniej ${ }^{16}$.

Specyfiką namibijskich obozów był ich zmienny charakter - trudno bowiem mówić, że były to obozy stricte wojskowe lub cywilne. Liczba mieszkańców poszczególnych obozów zmieniała się w czasie, stacjonowało w nich więcej bądź mniej żołnierzy PLAN, przy czym zawsze pozostawały otwarte na cywilnych uciekinierów z będącej pod władzą RPA Namibii. Interesujące jest, w jaki sposób sami Namibijczycy zmieniali formułę obozów. W zależności od organizacji lub delegacji (np. humanitarne, doradcy wojskowi, dyplomaci), które miały odwiedzić osiedle lub do których zwracano się o pomoc, mieszkańców nazywano uchodźcami (ang. refugees) bądź bojownikami (ang. freedom fighters). W taki sam sposób „formowano” obóz, aby odpowiadał aktualnej narracji. Z tego powodu tak trudno dzisiaj jednoznacznie stwierdzić, które obozy i w jakim okresie były obozami stricte wojskowymi, a w których przeważającą liczbę stanowili cywile ${ }^{17}$.

${ }^{15}$ C.A. Willi am s, Silence, voices, and ,the camp": perspectives on and from Southern Africa's exile histories, „Humanity: An International Journal of Human Rights, Humanitarianism and Development" 2012, vol. III, No. 1, s. 66.

${ }^{16}$ C.A. Williams, Exile history: an ethnography of the SWAPO camps and the Namibian nation, Cambridge 2015, s. 1.

${ }_{17}$ SWAPO, „The Namibian Refugee” (Luanda: SWAPO Dept. of Information and Publicity, 1988). 
Najważniejszą cechą wszystkich obozów było to, iż znajdowały się pod zwierzchnictwem SWAPO, działającej w porozumieniu z rządami państw, na terenie których istniały obozy ${ }^{18}$. W latach 1963-1989 w obozach administrowanych przez SWAPO, leżących w Tanzanii, Zambii ${ }^{19}$ i Angoli przebywało łącznie około 60 tysięcy osób. Każdy z obozów miał nieco inny charakter. Ich przeznaczenie można różnicować przede wszystkim ze względu na trwałość funkcjonowania. Część obozów, czy raczej obozowisk miała charakter mobilny i krótkotrwały. Były one niewielkie, organizowane doraźnie, na bieżące potrzeby żołnierzy PLAN, podczas prowadzenia akcji przeciwko siłom SADF ${ }^{20}$. Jednocześnie pełniły rolę tymczasowego miejsca zatrzymania dla ludzi uciekających z Namibii w głąb Angoli, do większych i stałych obozów. Obozowiska o charakterze ,krótkoterminowym"21 dla większości uciekinierów stanowiły kolejny przystanek na drodze do największych obozów. W tego typu miejscach można było otrzymać podstawową pomoc lekarską, ubrania lub żywność. Nie stacjonowały w nich na stałe oddziały PLAN, a podstawą obrony przed ewentualnym atakiem była słabo uzbrojona partyzantka złożona z aktualnych mieszkańców.

Najważniejsze obozy miały charakter stały. Były to de facto w pełni funkcjonujące osiedla. Na ich terenie dostosowywano istniejące budynki do potrzeb mieszkańców lub budowano nowe, powstawały szpitale i szkoły ${ }^{22}$. W obozach tych stacjonowały wyszkolone i dobrze uzbrojone wojska PLAN. Były to miejsca odwiedzane przez zagranicznych doradców wojskowych, przedstawicieli organizacji międzynarodowych oraz organizacje pomocowe. Osiedla te stanowiły de facto autonomiczne obszary pod zarządem SWAPO na terytoriach innych państw - nie miał do nich wstępu nikt z zewnątrz bez zgody władz obozu, kontaktowano się jedynie (w stopniu ograniczonym) z miejscową ludnością, z którą głównie handlowano ${ }^{23}$.

${ }^{18}$ SWAPO w 1976 r. została uznana przez ONZ za jedynego, prawdziwego wyraziciela woli wszystkich Namibijczyków. Na arenie międzynarodowej pełniła funkcję quasi-rządu, bezpośredniego „łącznika” pomiędzy ludnością Namibii a różnymi państwami i organizacjami. C.A. Willi a m s, Silence, voices, and ,the camp”..., s. 72.

${ }_{19} \mathrm{~W}$ publikacji nie podejmuję szerzej tematu obozów znajdujących się poza Angolą. Więcej informacji m.in. na temat ulokowanego na terytorium Tanzanii obozu Kongwa: C.A. Willams, Living in Exile: Daily Life and International Relations at SWAPO's Kongwa Camp, „Kronos” 2011, vol. XXXVII, No. 1, s. 60-86. Nieco informacji o obozie Nyango w Zambii m.in.: E.N. N a m hila, Mukwahepo. Woman, Soldier, Mother, Windhoek 2013, s. V-XI, 63-81; T. S el1strö m, Sweden and National Liberation in Southern Africa: Solidarity and assistance 1970-1994, Uppsala 2002, s. $266-267$.

${ }^{20}$ Ang. South African Defence Forces.

${ }^{21}$ W literaturze określa się je jako semi-permanent.

${ }^{22}$ W szkołach znajdujących się na terenie obozów uczyli najczęściej sami Namibijczycy, którzy kończyli odpowiednie kursy np. w Tanzanii lub Ghanie. SWAPO zajmowało się cywilnymi uciekinierami z Namibii zapewniając im możliwość edukacji, a później pracy wśród ,swoich”, w miejscach, gdzie byli najbardziej potrzebni. E.N. N a m hila, op. cit., s. VI.

${ }^{23}$ C.A. Willi a m s, Exile history..., s. 14. 
Można zakładać, że większość osób szukających schronienia na wygnaniu stanowili Owambo, zamieszkujący Owamboland, północną część Namibii, gdzie stacjonowało najwięcej oddziałów SADF, uderzających stamtąd na pozycje wojsk angolskich i kubańskich po północnej stronie rzeki Kunene. Dla Owambo, ucieczka do Angoli była, w sensie odległości, najprostszym rozwiązaniem. Dużo trudniej przedostać się tam było innym mieszkańcom Afryki Południowo-Zachodniej, takim jak Herero, Nama, Damara czy San. Część z nich, jak Hererowie, szukali schronienia w Botswanie i Zambii, lecz większość pozostała w kraju. Część Afrykanów współpracowała z władzami południowoafrykańskimi ${ }^{24}$.

Dołączenie do obozu było możliwe dla każdego, kto deklarował przynależność do ,narodu” namibijskiego, bez względu na pochodzenie etniczne. Nie oznaczało to, rzecz jasna, całkowitego wyrzeczenia się ,plemiennych” animozji. Na szczytach obozowej hierarchii poszczególne frakcje chętniej widziały swoich przedstawicieli, aniżeli kogoś pochodzącego z odmiennej grupy etnicznej, niemniej jednak wszyscy wspólnie zamieszkiwali i pracowali w jednym osiedlu ${ }^{25}$.

Jednak to właśnie obozowe realia sprawiły, że przynależność do ,jednego narodu" stała się, po pewnym czasie, podstawowym elementem łączącym wszystkich uciekinierów. Budowa tożsamości narodowej była świadomą polityką SWAPO, związaną zresztą z jej hasłami o ponadplemiennym porozumieniu i działaniu na rzecz wszystkich mieszkańców Namibii. Na tej fali, w 1973 r. w Lusace powstał projekt Namibijskiego Centrum Zdrowia i Edukacji ${ }^{26}$, którego celem miała być budowa przyszłego społeczeństwa w wolnej Namibii pod hasłem: „One Namibia, one People, one Nation" ${ }^{27}$. Budowanie poczucia przynależności do jednego narodu miało zaowocować w przyszłości. Już po uzyskaniu niepodległości chętnie sięgano do tradycji wygnańczej. Życie w obozie, który był traktowany jako namiastka własnego państwa, stało się symbolem, do którego często się odwoływano. To w obozach, poza granicami Namibii, według narracji przyjętej przez SWAPO, miał powstać ,jeden naród”. W czasie wojny, dla uciekających z Afryki Południowo-Zachodniej Namibijczyków obóz stanowił cel, miejsce dające pewność własnego losu.

Funkcjonowanie obozów pozostawało pod ścisłą kontrolą SWAPO. Organizacja decydowała o dystrybucji wszelkich dóbr, jedzenia, broni, a także wyznaczała osoby odpowiedzialne za poszczególne elementy działania osiedla.

${ }^{24}$ Jednym z przykładów czynnej współpracy są oddziały Koevoet (oficjalnie jako: SWAPOL-COIN), policji stworzonej przez władze RPA na terenie Namibii, w której pracowali głównie czarnoskórzy (najwięcej Owambo). Vide np.: J. H o o p e r, Koevoet! Experiencing South Africa's Gruelling Bush War, Rugby 2012.

${ }_{25}$ C.A. Willi a m s, Exile history..., s. 16.

${ }^{26}$ Ang. Namibian Health and Education Centre.

${ }^{27}$ University of Namibia, Katjavivi Collection, Series B1, Category 2, „Namibian Educational and Health Centre" 1973, s. 3. 
W komunikacji z mieszkańcami obozu pomagały „parady”, będące swego rodzaju apelem wojskowym, które odbywały się każdego dnia rano i stanowiły stały element życia w osiedlu. Podczas parady ludność mogła spotkać się nie tylko z zarządcami obozu, lecz także szefami SWAPO. Tego typu imprezy miały konsolidować mieszkańców osiedla, służyły budowaniu więzi pomiędzy władzami, wojskowymi i cywilami, a także tworzyły specyficzną atmosferę ciągłej gotowości bojowej, militaryzowały na pozór zwykłą osadę ${ }^{28}$.

Obozy były dobrze zorganizowane, choć pod względem logistycznym stworzenie sprawnie działających mechanizmów nie było łatwe ${ }^{29}$. Każdy mieszkaniec miał wyznaczoną rolę, pełnił konkretne funkcje i wykonywał powierzone mu zadania według swoich umiejętności i wykształcenia. Niebagatelną rolę w działaniu osiedli pełniły kobiety, zajmujące nawet wysokie stanowiska. Wiele z nich dopiero na wygnaniu mogło rozpocząć edukację, a część z nich - uzupełnić swoje wykształcenie do poziomu, jaki w zajętym przez RPA kraju dostępny był tylko dla mężczyzn ${ }^{30}$.

Współcześnie, w namibijskiej narracji historycznej obozy pełnią bardzo ważną rolę jako miejsca pamięci. To w pierwszym z nich, Ongulumbashe, rozpoczęła się wojna. Największy z obozów, Cassinga, była natomiast świadkiem najbardziej tragicznych wydarzeń w dziejach Namibii, a przez to pozostaje ona do dziś miejscem szczególnie ważnym dla Namibijczyków.

\section{Początek wojny - Ongulumbashe i obozy w Zambii}

Wojna o niepodległość Namibii rozpoczęła się w małej miejscowości Ongulumbashe w północno-zachodnim Owambolandzie, gdzie PLAN zorganizowała swoją pierwszą bazę. Była to pierwsza i, jak się miało okazać, ostatnia kryjówka PLAN na terytorium Namibii aż do końca wojny o niepodległość - władze SWAPO uznały bowiem, że utrzymywanie obozowiska w tak bliskiej odległości oddziałów SADF stanowi zbyt duże ryzyko. Choć baza była dobrze ukryta,

${ }^{28}$ C.A. Willia m s, ,Remember Cassinga?” an exhibition of photographs and histories, „Kronos" 2010, vol. XXXVI, No. 1, s. 230.

${ }^{29}$ Więcej na temat organizacji życia obozowego m.in.: Report on a mission to swapo centres for Namibian refugees in Angola from 10 to 14 April 1978, National Archives of Namibia, File A.614, UNICEF Area Office Brazzaville, s. 7; D. Sim on, R. Preston, Return to the promised land: the repatriation and resettlement of Namibian refugees, 1989-1990, referat zaprezentowany na konferencji pt. The Refugee Crisis: geographical perspectives on forced migration, Kings College London, 18-20 IX 1999, http://repository.forcedmigration.org/ pdf/?pid=fmo:765 (dostęp: 13 XI 2017).

${ }^{30}$ Przykładem może być kobieta nazywano Mukwahepo, tytułowa bohaterka książki pt. Mukwahepo. Woman, Soldier, Mother, zajmująca wysoką pozycję w obozie Kongwa. Pełniła ona rolę opiekunki, przewodnika nowo przybyłych, a nawet doradcy dla odwiedzających obóz władz SWAPO. Więcej w tej kwestii: E.N. Namhila, op. cit. 
wywiad południowoafrykański dowiedział się o niej dzięki pomocy opłacanych przez siebie szpiegów wśród Owambo, mieszkających w okolicy. Atak lotniczy na Ongulumbashe nastąpił 26 sierpnia 1966 r. Zbombardowanie obozu przez osiem helikopterów spowodowało nieodwracalne zniszczenia ${ }^{31}$. Pomimo militarnego zwycięstwa SADF, moralny tryumf odniosła SWAPO, gdyż atak na Ongulumbashe stał się dla Namibijczyków symbolem, niewspółmiernej do stawianego oporu, agresji RPA oraz poparcia dla SWAPO i jej metod zbrojnego oporu wobec Pretorii ${ }^{32}$.

Po zakończeniu tego starcia nastąpiły masowe zatrzymania działaczy SWAPO i podejrzewanych o kontakty z komunistami. Do połowy 1967 r. uwięziono około 150-200 osób, które następnie przewieziono na terytorium RPA. Wiele spośród nich poddano torturom ${ }^{33}$ i osadzono w więzieniu na Robben Island, w Kapsztadzie, miejscu skazania działaczy Afrykańskiego Kongresu Narodowego $^{34}$ (w tym Nelsona Mandelę). Aresztowano również ważnych członków SWAPO, m.in. Toivo Ya Toivo, Johna Ya Otto, Nathaniela Maxuilili i Jasona Mutumbula. Większość z nich została skazana na dożywocie, a dziewięciu (w tym Ya Toivo) na 20 lat pozbawienia wolności. W ramach represji, w okolicy Ongulumbashe, skazano na śmierć 63 cywilów ${ }^{35}$.

Po zniszczeniu obozu Ongulumbashe, PLAN przeniosło swoje kryjówki do Zambii, co było możliwe dzięki porozumieniu z niedawno wybranym prezydentem Kennethem Kaundą ${ }^{36}$. Jednak ataki na pozycje SADF prowadzone $\mathrm{z}$ terytorium Zambii były trudne i mało opłacalne, gdyż obywa terytoria dzielił długi pas podmokłych terenów (leżący w granicach Namibii), nazywany Caprivi. Odległość eliminowała możliwość zastosowania taktyki wojny partyzanckiej, jaką SWAPO zamierzało realizować, wzorując się na walkach ludności Nama z Niemcami z początku XX w. ${ }^{37}$

Najlepszą lokalizację dla obozów PLAN stanowiła południowa Angola, lecz ta znajdowała się wówczas pod kolonialną władzą Portugalczyków, którzy, w porozumieniu z RPA, eliminowali pojawiających się okazjonalnie w Angoli bojowników

${ }^{31}$ S. Nuj o ma, op. cit., s. 126-128; R. Dale, op. cit., s. 78.

${ }^{32}$ M. Walla ce, op. cit., s. 268.

${ }^{33}$ Miało wówczas miejsce pierwsze w dziejach RPA użycie tortur w rodzaju wstrząsów elektrycznych.

${ }^{34}$ Ang. African National Congress (ANC).

${ }_{35}$ P.H. Katjavivi, op. cit., s. 61-63.

${ }^{36}$ Zambia, wcześniej Rodezja Północna, uzyskała niepodległość w 1964 r.

37 Więcej na temat wojny Namibjczyków z Niemcami m.in.: H. B ley, Namibia under German Rule, Hamburg 1996; H. Dre ch sler, Let Us Die Fighting: The Struggle of the Herero and Nama against German Imperialism 1884-1915, London 1980; J.-B. Gew ald, Herero Heros: a Sociopolitcal History of the Herero of Namibia 1890-1923, Oxford 1999; D. Ol u s o g a, C.W. Er i c h s e n, Zbrodnia kajzera, Warszawa 2012. 
namibijskich. Sytuacja uległa zmianie w roku 1975 r., kiedy Angola ogłosiła niepodległość, a władzę przejęła, współpracująca z Kubą i ZSRS, partia MPLA ${ }^{38}$. Rok później PLAN przeniosła większość kryjówek do południowej Angoli, a SWAPO utworzyła w Luandzie własne biuro ${ }^{39}$.

Działania PLAN w początkowych latach funkcjonowania na obczyźnie były mało skoordynowane i często kłopotliwe dla władz centralnych państw, na których terenie miały miejsce. Choć kierownictwo, przebywające głównie blisko siedziby ONZ lub w Tanzanii, dawało ogólne wytyczne, nie panowało nad dyscypliną na najniższych szczeblach oraz ambicjami niektórych, niższych rangą, dowódców. Kryzys w partii, w literaturze nazywany niekiedy „szpiegowskim”, zakończył się licznymi aresztowaniami przez zambijskie i tanzańskie służby (najczęstszym oskarżeniem była korupcja), najprawdopodobniej z przyzwoleniem Sama Nujomy i najwyższych władz SWAPO ${ }^{40}$.

Reorganizacja SWAPO stała się koniecznością. Sformułowanie nowych struktur i metod walki powierzono specjalnie powołanej komisji wewnętrznej, na czele której stanął John Ya Otto. Nowy program działań przedstawiono w lipcu 1976 r., podczas spotkania komitetu centralnego SWAPO. Oprócz zaznaczenia, że partia została zinfiltrowana, w wyniku czego doszło do „rewolty”41, określono zadania stojące przed organizacją. Najważniejsze z nich pozostawało niezmienne, była to walka o wyzwolenie Namibii. Obok przedstawionych koncepcji militarnej konfrontacji znalazły się w nim ponadto postulaty dotyczące opieki nad ludnością mieszkającą poza Namibią, często w prowizorycznych obozach dla uchodźców w Angoli, organizacja szkolnictwa oraz systemu opieki zdrowotnej. Dzięki tym założeniom usystematyzowano pomoc dla Namibijczyków uciekających przed wojną i apartheidem oraz rozpoczęto budowę stałych obozów w formie osiedli, gdzie mieszkali wspólnie cywile i wojskowi.

$\mathrm{W}$ drugiej połowie lat siedemdziesiątych sytuacja w partii ustabilizowała się, co spowodowało poprawę relacji z władzami Zambii, a także polepszenie sytuacji SWAPO w Angoli. Dzięki porozumieniu z Lusaką i Luandą, w obydwu państwach powstało kilka dużych obozów pod protektoratem SWAPO: Nyango w Zambii oraz Kwanza Sul, Lubango i Cassinga w Angoli ${ }^{42}$.

${ }_{38}$ Port. Movimento Popular de Libertação de Angola (Ludowy Ruch Wyzwolenia Angoli).

${ }^{39}$ W. Minter, Apartheid's Contras:An Inquiry into the Rootsof War in Angola and Mozambique, London 1994, s. 30.

${ }^{40} \mathrm{P}$. Trewhela, The Kissinger/Vorster/Kaunda detente: Genesis of the swapo „spy-drama”, „Searchlight South Africa” 1990, vol. II, No. 2, s. 69-85; C.A. Willi a m s, Exile history..., s. 74-76; M. Walla ce, op. cit., s. 280-281.

${ }^{41}$ Wiele wskazuje na to, że kryzys w partii i bunt młodszych członków wykorzystało jej kierownictwo, aby umocnić swoją pozycję. C.A. Willi a m s, Exile history..., s. 110-112.

${ }^{42}$ M. Wallac e, op. cit., s. 282. 


\section{Obozy w Angoli - Lubango i Cassinga}

Pomimo pozytywnej roli, jaką obozy odegrały w budowaniu ,jedności narodu”, jeden z nich, Lubango, w dziejach Namibii stanowi wyjątkowo ciemną i nadal niezbadaną kartę. W latach osiemdziesiątych w SWAPO narastał konflikt wewnętrzny. Podejrzewano, że pośród członków wszystkich szczebli partii znajdują się szpiedzy, współpracujący z południowoafrykańskim wywiadem. W celu ich eliminacji powołano instytucję kontrwywiadowczą. Oskarżonych o szpiegostwo na rzecz rządu RPA osadzono w specjalnie utworzonym więzieniu, znajdującym się na terenie obozu Lubango. Prawdopodobnie oprócz osób słusznie podejrzewanych, większość tam uwięzionych stanowili polityczni przeciwnicy SWAPO. Choć brak na to dowodów, gdyż dla SWAPO jest to temat wyjątkowo niewygodny, to nadal żyje wielu świadków, którzy przeżyli to więzienie. Jego historia stanowi haniebny epizod walki wyzwoleńczej Namibijczyków. Na terenie obozu, według ustnych przekazów, więźniowie byli dręczeni i torturowani, a kobiety wykorzystywane seksualnie. Łączna liczba skazanych na śmierć lub zmarłych z powodu chorób w Lubango to ponad 4 tysiące osób. Temat ten jest w Namibii wciąż rzadko podejmowany ${ }^{43}$.

Oddziały PLAN pojawiły się na południu Angoli w pierwszej połowie 1975 r., jeszcze zanim władze SWAPO zdecydowały ostatecznie o współpracy z partią MPLA $^{44}$. Na początku 1976 r. SWAPO działało już w porozumieniu z MPLA, która zgodziła się wesprzeć bliski jej ruch wyzwoleńczy z sąsiadującego państwa ${ }^{45}$. Udostępnienie terytorium umożliwiło oddziałom PLAN przeniesienie ludzi na teren leżący bliżej Namibii. Dla Namibijczyków przeznaczono opuszczone wsie, skąd Angolczycy uciekli podczas niedawno zakończonej wojny wyzwoleńczej lub aktualnie rozwijającej się wojny domowej ${ }^{46}$.

Najbardziej znany spośród namibijskich obozów znajdował się $260 \mathrm{~km}$ od granicy z Namibią w miejscowości Cassinga i został założony w pierwszej połowie 1976 r. Początkowo miał charakter „tymczasowy” i nic nie zapowiadało, że stanie się tak ważnym punktem na „wygnańczej” mapie SWAPO. Sam przyjazd do Cassingi sprawiał dość duży kłopot: żołnierze, przebywający na terenie Zambii lub Tanzanii byli transportowani drogą powietrzną do Luandy, skąd autobusami dowożono ich do Huambo (jest to drugie co do wielkości miasto Angoli),

${ }^{43}$ Lessons of Lubango, „The Namibian”, 24 V 2005.

44 W kwietniu 1975 r. zarówno MPLA, jak UNITA zgodziły się, aby SWAPO założyła swoje bazy w południowej Angoli. W sierpniu UNITA wycofała swoje poparcie i rozkazała SWAPO opuścić południowo-wschodnią część Angoli. SWAPO przeniosło się na tereny kontrolowane przez MPLA w południowo-zachodniej części kraju. A. Shipanga, In Search of Freedom, Gibraltar 1989, s. 102-103; C.A. Willi a m s, Exile history..., s. 91-92; Modern African Wars, Sout West Africa, http://kohlibri.e-bookshelf.de/products/reading-epub/page/13/product-id/707743/title/Modern \%2BAfrican\%2BWars\%2B\%25283\%2529.html?firm=\%22OS PREY\%22 (dostęp: 16 XI 2017).

${ }^{45}$ C.A. Willi a m s, Exile history..., s. 138-139.

${ }^{46}$ Truth Commision Special Report, vol. II, chapter 2, s. 49. 
a dopiero stamtąd, kolejnymi autobusami i samochodami terenowymi - do Cassingi, która znajdowała się w połowie drogi pomiędzy Huambo a namibijską granicą. W Cassindze partyzanci spędzali przeważnie jedną noc przed ruszeniem do ataku na południowoafrykańskie wojska stacjonujące w Owambolandzie. Tylko niewielka część PLAN została ulokowana w obozie jako oddział defensywny ${ }^{47}$.

Z czasem jednak obóz w Cassindze powiększał się, zmieniając swój charakter. $\mathrm{Z}$ powodu rosnącej liczby żołnierzy, przebywających tam na stałe bądź czasowo, konieczne stało się utworzenie izby lekarskiej, poprawy jakości zabudowań, stałego dostępu do leków i żywności. To z kolei spowodowało pojawienie się cywilów, zarówno tych przebywających już w Angoli, jak kolejnych, nowych uciekinierów z Namibii. Cassinga stała się prężnie działającym centrum. Dawne portugalskie zabudowania przystosowano do bieżących potrzeb, W Cassindzie ulokowano stałe biuro PLAN oraz koszary dla rekrutów, założono niewielki szpital (zajmujący się głównie doraźnymi przypadkami i rannymi żołnierzami; bardziej poważne przypadki były transportowane do większych lecznic w Lubango i Jambie ${ }^{48}$ ), postawiono zabudowania mieszkalne, wyznaczono pola uprawne oraz miejsce cmentarne $^{49}$. Życie codzienne w Cassindze upływało na powtarzalnych czynnościach: nauce, pracy i okazjonalnych rozrywkach. Gdyby nie wspominane wcześniej parady wojskowe, które codziennie przypominały mieszkańcom, dlaczego znajdują się w tym miejscu i co próbują odzyskać, Cassinga przypominałaby zwyczajną osadę. Mieszkańcy obozu utrzymywali regularne kontakty z mieszkającymi nieopodal Angolczykami oraz Kubańczykami ${ }^{50}$, którzy stacjonowali w swoim obozie Techamutete. Wielu Namibijczyków miało rodziny w pobliskim mieście Jamba, gdzie często podróżowali ${ }^{51}$.

Niedaleko Cassingi, niemal w tym samym czasie powstał drugi obóz, Chatequera, o którym rzadko wspomina się w literaturze. Chatequera był bowiem obozem stricte wojskowym, a władze SWAPO niechętnie przyznawały, że tego typu obozy istniały, gdyż nie pasowało to do narracji dotyczącej „,bezbronnych”, cywilnych obozów, atakowanych przez SADF ${ }^{52}$.

W pierwszej połowie 1978 r. PLAN zaobserwowała wzmożoną aktywność sił SAAF na niebie nad obozami ${ }^{53}$, jednak nie przewidziano zamierzeń południowoafrykańskich wojsk. 3 maja 1978 r. SAAF rozpoczęło atak na pozycje PLAN od zbombardowania obozów Cassinga i Chatequera. Następnego dnia w pobliżu obozów dokonano zrzutu spadochronowych wojsk specjalnych. Namibijczycy

${ }^{47}$ C.A. Willi a m s, Exile history..., s. 35.

${ }^{48}$ C.A. William s, „Remember Cassinga?”..., s. 222.

${ }^{49}$ Ibidem, s. 217.

${ }^{50}$ P. Gleije ses, Visions of Freedom. Havana, Washington and Pretoria and the Struggle for Southern Africa 1976-1991, Chapel Hill 2013, s. 209.

${ }^{51}$ C.A. Willi a m s, ,Remember Cassinga?”..., s. 224.

${ }^{52}$ Ibidem, s. 232.

${ }^{53}$ Ibidem, s. 226. Ang. South African Air Forces. 
zostali niemal całkowicie zaskoczeni i, chociaż PLAN szybko sformowała koncepcję obrony, a na pomoc ruszyli Kubańczycy, nie było czasu ani możliwości ewakuacji cywilów z terenu walki. W wyniku bombardowań i podczas starć zginęło około 400-600 żołnierzy PLAN oraz 3-4 tys. cywilów. Dla współczesnych Namibijczyków Cassinga stała się symbolem nierównej walki z apartheidowskim reżimem ${ }^{54}$. Obóz ten stał się jednym z najważniejszych miejsc pamięci dla całego narodu, a dzień 4 maja świętem państwowym pod nazwą Cassinga Day ${ }^{55}$.

Pomimo dotkliwej porażki, PLAN kontynuowała walki. Od czasu bombardowania Cassingi zintensyfikowała się współpraca między Namibijczykami a wojskami kubańskimi, stacjonującymi w Angoli (w rosnącej z roku na rok liczbie). Pozostałe obozy, zarówno cywilne, jak wojskowe nie opustoszały, w dalszym ciągu pełniąc istotną rolę w swoistej diasporze mieszkańców Namibii.

Ustabilizowanie sytuacji w całym regionie Afryki Południowej było możliwe dzięki dobrej, międzynarodowej koniunkturze, rozpadowi Związku Sowieckiego i wyparciu się polityki apartheidu przez RPA. Czynniki o znaczeniu globalnym umożliwiły, w głównej mierze, ogłoszenie niepodległości przez Namibię, co nastąpiło w marcu 1990 r. Od tego czasu Namibia, jako suwerenne państwo, musiała zmierzyć się z innego rodzaju wyzwaniami. Jednym z nich było sprowadzenie do kraju wszystkich uciekinierów, uchodźców i żołnierzy PLAN oraz zapewnienie im warunków do rozpoczęcia nowego życia ${ }^{56}$. Opuszczenie obozów i powrót do ojczyzny zamykał jeden z najważniejszych rozdziałów w historii młodego narodu, którego tożsamość, w dużej mierze, ukształtowała się właśnie na obczyźnie.

\section{Bibliografia}

\section{ŹRÓDEA ARCHIWALNE}

National Archives of Namibia, File A.614, UNICEF Area Office Brazzaville

Report on a mission to swapo centres for Namibian refugees in Angola from 10 to 14 April 1978.

\section{ŹRÓDŁA DRUKOWANE}

„The Namibian Refugee”, SWAPO Dept. of Information and Publicity in Luanda, 1988.

Truth Commision Special Report, vol. II, chapter 2.

${ }^{54}$ Dzień 4 maja jest świętem narodowym. P. Gleijes es, From Cassinga to New York. The Struggle for the Independence of Namibia, [w:] Cold War in Southern Africa. White Power, Black Liberation, ed. S. Onslow, New York 2009, s. 201.

${ }^{55}$ Namibijczycy szczególną pamięcią czczą dwa wydarzenia w swojej historii: ludobójstwo, jakiego dokonały kolonialne władze niemieckie w latach 1904-1907 oraz dzień bombardowania Cassingi. Są to najsmutniejsze epizody w dziejach narodu, szczególnie ważne, ze względu na śmierć tysięcy cywilów. Cassinga Day In A Contemporary Context, „,The Namibian”, 5 V 2017.

${ }^{56}$ D. Simon, R. Presto n, op. cit. 
University of Namibia, Katjavivi Collection, Series B1, Category 2, „Namibian Educational and Health Centre" 1973, s. 3.

\section{OPRACOWANIA}

Dale R., The Namibian War of Independence 1966-1989. Diplomatic, Economic and Military Campaigns, Jefferson 2014.

Gleijeses P., From Cassinga to New York. The Struggle for the Independence of Namibia, [w:] Cold War in Southern Africa. White Power, Black Liberation, ed. S. Onslow, New York 2009, s. 201-225.

Gleijeses P., Visions of Freedom. Havana, Washington and Pretoria and the Struggle for Southern Africa 1976-1991, Chapel Hill 2013.

Hooper J., Koevoet! Experiencing South Africa's Gruelling Bush War, Rugby 2012.

Katjavivi P.H., A History of Resistance in Namibia, New York 1990.

Minter W., Apartheid's Contras: An Inquiry into the Rootsof War in Angola and Mozambique, London 1994.

Namhila E.N., Mukwahepo. Woman, Soldier, Mother, Windhoek 2013.

Nujoma S., Where Other Waverd. The Autobiography of Sam Nujoma, London 2001.

Sellström T., Sweden and National Liberation in Southern Africa: Solidarity and assistance 1970-1994, Uppsala 2002.

Shipanga A., In Search of Freedom, Gibraltar 1989.

Trewhela P., The Kissinger / Vorster / Kaunda detente: Genesis of the swapo „spy-drama”, „Searchlight South Africa" 1990, vol. II, No. 2, s. 69-86.

Tsokodayi C.J., Namibia's Independence Struggle. The Role of United Nations, Bloomington 2011.

Wallace M., A History of Namibia, London 2011.

Williams C.A., Exile history: an ethnography of the SWAPO camps and the Namibian nation, Cambridge 2015.

Williams C.A., Living in Exile: Daily Life and International Relations at SWAPO's Kongwa Camp, „Kronos” 2011, vol. XXXVII, No. 1, s. 60-86.

Williams C.A., „Remember Cassinga? ” an exhibition of photographs and histories, „Kronos” 2010, vol. XXXVI, No. 1, s. 213-250.

Williams C.A., Silence, voices, and ,the camp": perspectives on and from Southern Africa's exile histories, „Humanity: An International Journal of Human Rights, Humanitarianism and Development" 2012, vol. III, No. 1, s. 65-95.

\section{Netografia}

Cassinga Day In A Contemporary Context, „The Namibian”, 5 V 2017.

Lessons of Lubango, „The Namibian”, 24 V 2005.

Modern African Wars, Sout West Africa, http://kohlibri.e-bookshelf.de/products/reading-epub/ page/13/product-id/707743/title/Modern\%2BAfrican\%2BWars\%2B\%25283\%2529.html ?firm $=\% 22$ OSPREY\%22 (dostęp: 16 XI 2017).

Simon D., Preston R., Return to the promised land: the repatriation and resettlement of Namibian refugees, 1989-1990, referat zaprezentowany na konferencji pt. The Refugee Crisis: geographical perspectives on forced migration, Kings College London, 18-20 IX 1999, http://repository. forcedmigration.org/pdf/? pid=fmo:765 (dostęp: 13 XI 2017). 


\title{
ANNA SzCZEPAŃSKA
}

\section{From Ongulumbashe to Cassinga - military and civil camps of People's Liberation Army of Namibia}

\begin{abstract}
The history of the Republic of Namibia began in 1990 when the declaration of independence was proclaimed, after 25 years of liberation struggle with South Africa regime. However the national identity had been shaping many years before. One of the most important component of creating „one Namibia, one People, one Nation” (which was a SWAPO slogan from party's project of 1973) were camps: civil for refugees and military for freedom fighters organized by People's Liberation Army of Namibia, located in Angola, Zambia and Tanzania. The purpose of the article is introducing the most crucial moments of Nambian camps history, selected elements of their daily life and the role of the camps in contemporary Namibia.
\end{abstract}

Keywords: Namibia, camps, SWAPO, PLAN, independence. 